\title{
Ice-forming Nuclei and Their Dominant Source Region
}

\author{
By R.K. Kapoor, R.S. Sekhon, A.S. Ramachandra Murty \\ and \\ Bh. V. Ramana Murty \\ Institute of Tropical Meteorology, India Meteorological Department, Poona, India \\ (Manuscript received 22 March 1969)
}

\begin{abstract}
The results of analysis of the data collected on the concentrations of the ice-forming and other forms of nuclei in a few places in India (Delhi, Calcutta, Bombay, Lonavla and Poona) have been presented. The ice-forming nuclei have varied generally inversely with the chloride nuclei at Delhi, Bombay and Poona. The ice-forming and hygroscopic nuclei have shown negative correlation at Delhi. The ice-forming and non-hygroscopic nuclei have varied on parallel lines at Poona. The relatively large value of the ice-forming nuclei noticed at Delhi as compared to that at Calcutta has been seen reflected in the high value of the non-hygroscopic nuclei observed in that region. The observations have suggested that the main source for the ice-forming nuclei in the regions measured is the land. The possibility of the continental dust being responsible for the observed ice nuclei counts in the maritime air has been pointed out.
\end{abstract}

\section{Introduction}

Ice-forming nuclei which play a dominant role in the release of precipitation from supercooled clouds constitute a very tiny fraction of the total particulate matter in the air. The nature, concentration and source regions of these nuclei have become matters of great interest eversince their importance in the precipitation processes has been recognized. An important characteristic noticed of the nuclei is their variability with time-inter-diurnal and, sometimes, intradiurnal (Bourquard, 1963). This feature has implication in the studies aimed at understanding their source regions in that it necessitates averaging over a longer series of observations for securing meaningful interpretation of the data.

Several studies have been made tracing the origin of the natural ice-forming nuclei to the sea (Brier and Kline; 1959; Battan and Riley, 1960), to the land (Isono et al 1959; Price and Pales, 1964), to the stratosphere (Bigg and Miles, 1963) and to extra terrestrial sources (Maruyama and Kitagawa, 1967). Based on measurements made at Delhi $\left(28^{\circ} 35^{\prime} \mathrm{N}, 77^{\circ} 12^{\prime} \mathrm{E}, 210\right.$ meters A.M.S.L.) Ramana Murty et al (1967) suggested that the source region of the ice-forming aerosols in the region is more than one and that it is maritime, continental, stratospheric and extra terrestrial. However it could not be examined with the limited observations available then which source region is more predominant than another and which is the most predominant source region. The programme of study of the ice-forming and other nuclei besides being continued at Delhi has subsequently been extended to Bombay $\left(19^{\circ} 07^{\prime} \mathrm{N}\right.$, $72^{\circ} 51^{\prime} \mathrm{E}, 14$ metres A.M.S.L.), Lonavla $\left(18^{\circ} 45^{\prime} \mathrm{N}\right.$, $73^{\circ} 24^{\prime}$ E, 625 metres A.M.S.L. $)$, Poona $\left(18^{\circ} 32^{\prime}\right.$ N, $73^{\circ} 51^{\prime} \mathrm{E}, 559$ metres A.M.S.L.) and Calcutta $\left(22^{\circ} 39^{\prime} \mathrm{N}, 8^{\circ} 27^{\prime} \mathrm{E}, 6\right.$ metres A.M.S.L.), though the observations made in these regions have been limited to very small periods. It is the purpose of the present paper to examine, in the light of the data available for different regions in the country, which one of the first two sources stated above, i.e. sea and land, is the more predominant source region for these nuclei. For the purpose of the present study nuclei of land origin have been taken to mean those particulate matters which are produced on the surface of the earth by all natural and man-made processes.

\section{Measurements}

As the concentration of chloride aerosols is generally considered to be indicative of marine influence, measurements on the chloride particle 
Table 1.

\begin{tabular}{|c|c|c|c|c|}
\hline \multirow{2}{*}{ Place } & \multicolumn{4}{|c|}{ Period during which nuclei measuremnts made } \\
\hline & Ice-forming & Hygroscopic & Non-hygroscopic & Chloride \\
\hline \multirow{2}{*}{ DELHI } & $\begin{array}{c}\text { March } 1962- \\
\text { April } 1963 \\
\text { (208) }\end{array}$ & $\begin{array}{c}\text { March } 1962- \\
\text { October } 1962 \\
(86)\end{array}$ & $\begin{array}{c}\text { March } 1962- \\
\text { October } 1962 \\
(86)\end{array}$ & $\begin{array}{l}\text { March 1965- } \\
\text { February } 1966 \\
(287)\end{array}$ \\
\hline & $\begin{array}{c}\text { March } 1965- \\
\text { February } 1966 \\
(275)\end{array}$ & $\begin{array}{c}\text { March 1965- } \\
\text { February } 1966 \\
(262)\end{array}$ & $\begin{array}{c}\text { March } 1965- \\
\text { February } 1966 \\
(262)\end{array}$ & - \\
\hline CALCUTTA & $\begin{array}{c}\text { December } 1966- \\
\text { February } 1967 \\
(33)\end{array}$ & $\begin{array}{c}\text { December } 1966- \\
\text { February } 1967 \\
(70)\end{array}$ & $\begin{array}{c}\text { December } 1966- \\
\text { February } 1967 \\
(70)\end{array}$ & - \\
\hline BOMBAY & $\begin{array}{c}\text { June } 1968 \\
(6)\end{array}$ & $\begin{array}{c}\text { June } 1968 \\
(6)\end{array}$ & $\begin{array}{c}\text { June } 1968 \\
(6)\end{array}$ & $\begin{array}{c}\text { June } 1968 \\
(6)\end{array}$ \\
\hline LONAVLA & $\begin{array}{c}\text { June } 1968 \\
(6)\end{array}$ & $\begin{array}{c}\text { June } 1968 \\
(6)\end{array}$ & $\begin{array}{c}\text { June } 1968 \\
(6)\end{array}$ & $\begin{array}{c}\text { June } 1968 \\
(6)\end{array}$ \\
\hline POONA & $\begin{array}{c}\text { December } 1967- \\
\text { June } 1968 \\
(127)\end{array}$ & $\begin{array}{c}\text { December } 1967- \\
\text { June } 1968\end{array}$ & $\begin{array}{c}\text { December } 1967- \\
\text { June } 1968 \\
(100)\end{array}$ & $\begin{array}{c}\text { June } 1968 \\
(6)\end{array}$ \\
\hline
\end{tabular}

content have been made at Delhi, Bombay, Lonavla, and Poona along with measurements on the ice-forming nuclei. Also, the concentrations of the total hygroscopic and non-hygroscopic aerosols, which in a way represent marine and continental influences respectively, have been measured, in the giant size range $(1$ micron and above in radius), at all the places. Measurements have been extended to the lower sizes possible (upto 0.25 micron radius) in the case of Bombay, Lonavla and Poona and the concentrations obtained in the entire size range covered have been considered for these places. A microwave radar was in operation at the place of work in Delhi and the structure of raincells in the region on the days of nuclei measurements, when there was also precipitation, was obtained by the radar.

Details relating to the aerosol observations made at each place are given in Table 1. Figures within brackets in the table denote the total number of observational days during the periods stated.

The site of sampling at each place, being the terrace of $\mathrm{radar} /$ radiosonde/laboratory/office building, was relatively free from the influence of local pollutions. Sampling was done in the afternoon hours when thermal convection is considered to be at its maximum in mixing the air near the ground with the air above. The equipment employed for the study of the ice-forming and chloride aerosols was the millipore filter assembly, first developed and applied by Lodge (1954). Ice nuclei measurements have been made at $-15^{\circ} \mathrm{C}$ on the exposed millipore filters as described by Bigg et al (1963). Chloride, hygroscopic and nonhygroscopic aerosol measurements have been made in the manner described by Kapoor and Ramana Murty (1966). Though the chlorides measured were grouped into two size classes, namely, 'large' (radius from 0.1 to 1.0 micron) and 'giant' (radius more than 1 micron), their total concentration only has been considered in the present study. As the limit of detection of chloride aerosols measured in the large size range did not extend well into the small size end, missing of chloride particles below 0.5 micron was not ruled out.

\section{Analysis and results}

(a) Daily variation in the concentration of ice-forming and chloride nuclei at Delhi.

The day-to-day variation noticed in the concentration of the ice-forming nuclei (the value varied from nil on certain days to a hundred or more on certain other days) has been critically examined vis-a-vis that of the chloride particles. The daily values for July and December months, characteristic of monsoon and winter periods, are shown plotted in Figures 1 (a) and 1 (b) respectively for the purpose of illustration.

Significant variations in the ice-nuclei concentration are not associated, in any specific manner, with the variations noticed in the chloride particle 


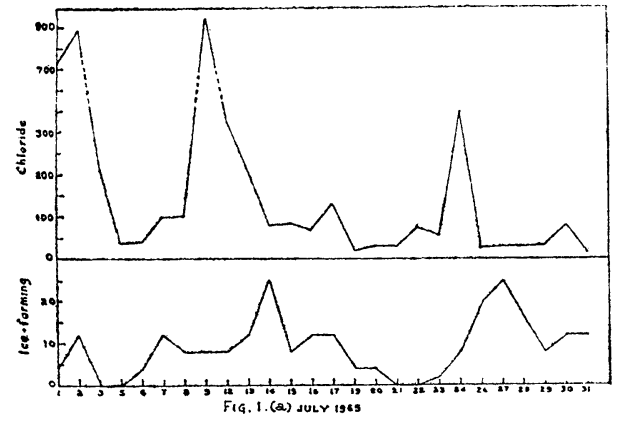

Fig. 1 (a). Daily concentration of ice-forming $\left(\mathrm{no} / \mathrm{m}^{3}\right.$ at $\left.-15^{\circ} \mathrm{C}\right)$ and chloride (no/1) nuclei at Delhi.

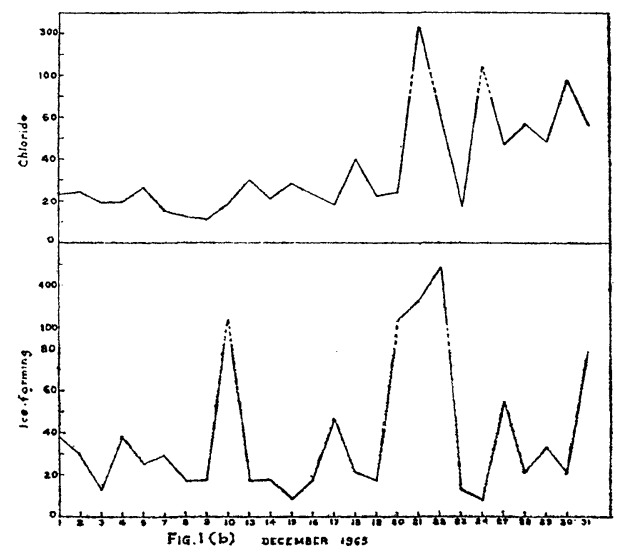

Fig. 1 (b). Daily concentration of ice-forming $\left(\mathrm{no} / \mathrm{m}^{3}\right.$ at $\left.-15 \mathrm{C}^{\circ}\right)$ and chloride (no/1) nuclei at Delhi.

concentration. However, some trend is seen to emerge when values of the monthly averages have been considered. The seasonal averages have revealed distinct differences.

(b) Monthly and seasonal variation of iceforming and chloride nuclei at Delhi.

Monthly mean values of ice-forming and chloride nuclei concentrations are shown plotted in Fig. 2. High values of ice nuclei are generally associated with low values of chloride aerosols suggesting non-marine origin to the former. The correlation coefficient ' $r$ ' between chloride and ice nuclei concentration is -0.578 , significant at 5 per cent level. It may be noted that the correlation coefficient between sea salt and ice-forming nuclei as found by Georgii and Metnieks (1958) has been also negative but not statistically significant.

If the mean values seasonwise for the monsoon (July-September) and winter (December-February)

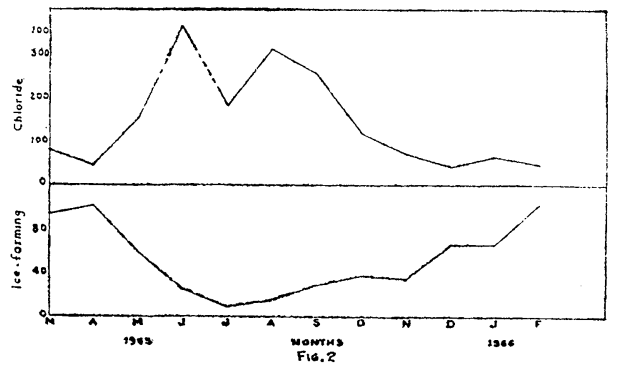

Fig. 2. Monthly mean concentration ice-forming $\left(\mathrm{no} / \mathrm{m}^{3}\right.$ at $\left.-15^{\circ} \mathrm{C}\right)$ and chloride (no/1) nuclei at Delhi.

Table 2.

\begin{tabular}{lcc}
\hline Season & \multicolumn{2}{c}{ Concentration of nuclei } \\
\cline { 2 - 3 } & $\begin{array}{c}\text { Ice-forming } \\
\left(\mathrm{no} / \mathrm{m}^{3} \text { at }-15^{\circ} \mathrm{C}\right)\end{array}$ & $\begin{array}{c}\text { Chloride } \\
(\mathrm{no} / 1)\end{array}$ \\
\hline Monsoon & 17.7 & 245.9 \\
Winter & 77.7 & 48.9
\end{tabular}

are considered (Table 2), striking differences are noticed between the two seasons.

The concentration of the ice-forming nuclei is higher $\left(77.7 / \mathrm{m}^{3}\right)$ during winter when the feed of air into the region is mostly from the dry inland regions to the west. It is markedly less $\left(17.7 / \mathrm{m}^{3}\right)$ during monsoon when the feed is mostly from the sea and the intervening land is considerably wet. High chloride concentration is associated with low ice nuclei count and vice versa. The features point out that land is the dominant source region for the ice-forming nuclei.

(c) Ice-forming, hygroscopic and non-hygroscopic nuclei at Delhi considered daily, monthly and season-wise.

Long series of observations are available for the period 1962-63 and 1965-66. Examination of the day-to-day values of the ice-forming, hygroscopic and non-hygroscopic nuclei for neither year-these are not presented-has suggested any consistent relationship. If the monthly mean values are considered (see Fig. 3 giving the values for the period 1965-66), it is seen that higher values of the ice nuclei were generally associated with lower values of the hygroscopic nuclei suggesting non-marine origin to the ice nuclei. However, no specific relation was noticed between the ice nuclei and the non-hygroscopic nuclei. The correlation coefficient between the ice-forming and the hygroscopic nuclei (Fig. 3) is -0.650 , 
Table 3.

\begin{tabular}{ccccc}
\hline $\begin{array}{c}\text { Dominant rain } \\
\text { mechanism }\end{array}$ & $\begin{array}{c}\text { Number of } \\
\text { occasions }\end{array}$ & \multicolumn{2}{c}{ Concentration of nuclei per litre at Delhi } & $\begin{array}{c}\text { Ratio of chloride } \\
\text { to ice-forming } \\
\text { nuclei }\end{array}$ \\
\hline 'WARM' & 10 & Ice-forming & Chloride & $13.5 \times 10^{3}$ \\
'COLD' & 25 & $16.4 \times 10^{-3}$ & 221.3 & $1.2 \times 10^{3}$ \\
\hline
\end{tabular}

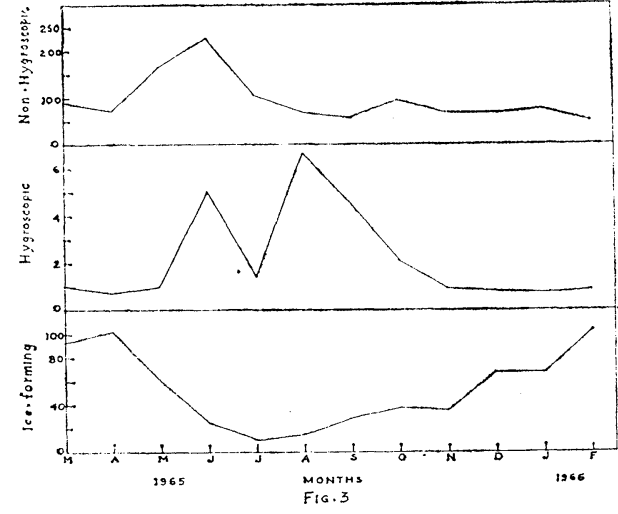

Fig. 3. Monthly mean concentration of iceforming (no/m $\mathrm{m}^{3}$ ), hygroscopic (no/1) and non-hygroscopic (no/1) nuclei at Delhi.

significant at 2 per cent level, while that between the ice-forming and the non-hygroscopic nuclei is -0.276 , not significant at 10 per cent level.

(d) Concentration of ice-forming and chloride nuclei and the dominant rain mechanism at Delhi.

Information relating to the dominant type of precipitating cloud in the region was obtained from examination of pictures taken with the high power $3.2 \mathrm{~cm}$ weather radar which was in regular use at Delhi for cloud physics studies (Ramana Murty et al., 1960). Based on criteria of height of echo top vis-a-vis freezing level, and of association or otherwise of cold rain cells with the melting band indicative of rain by ice process, the precipitating clouds and thereby the observational days have been classified. If the echo on radar was confined below the freezing level, the precipitating cloud was 'warm'. But, if the echo top was well above the freezing level and also well developed melting band was seen, the cloud under question was 'cold'. Mean concentrations of the ice-forming and chloride nuclei on the two groups of days classified according to the dominant type of the precipitating cloud observed, are given in Table 3.
The ice nuclei concentration was high on the days associated with 'cold' rain $\left(45.5 / \mathrm{m}^{3}\right)$ and low on days associated with 'warm' rain $\left(16.4 / \mathrm{m}^{3}\right)$. As far as the chloride concentration is concerned, it was found low with 'cold' rain $(56.3 / l)$ and high with 'warm' rain days (221.3/1) pointing once again the inverse relation of the ice-forming nuclei with chloride aerosols.

The observations lend support to the view that development of ice-phase in the cloud is more associated with ice-forming nuclei in the air, as is to be expected on such occasions of rain development by the Findeisen-Bergeron process. The higher concentration of chlorides as noticed in the air on 'warm rain' days (221.3/1) is also consistent with the generally accepted view that development of rain on such occasions is facilitated by presence in the air of such particles by collision-coalescence mechanism. In the last column of Table 3 is also given the ratio of chloride to ice nuclei concentration. While in the case of 'warm rain' days this ratio is as high as $13.5 \times$ $10^{3}$, it is only $1.2 \times 10^{3}$ in the case with 'cold rain'. The finding suggests the possibility of such ratio being used as indicator of the kind of rain mechanism operating in the cloud.

(e) Ice-forming and chloride nuclei in dust storms at Delhi.

The mean concentration of the ice-forming and chloride aerosols for 101 clear days and 23 dust storm days, as available, have been examined (Table 4). The ratio of the concentration of the chloride aerosols to that of the ice-forming aeroslos was high on dust storm days $\left(11.2 \times 10^{3}\right)$ as compared to that on clear days $\left(2.6 \times 10^{3}\right)$. However, it is to be noted that whereas the mean concentration of the chloride aerosols increased by about five fold on dust storm days, the concentration of the ice-forming nuclei remained nearly the same as on clear days. Rosinski (1967) found ice nuclei concentrations in dust storms to be the same as or lower than that outside the storm area indicating that if the ice-forming nuclei are of land origin, only certain types 
Table 4.

\begin{tabular}{|c|c|c|c|c|}
\hline \multirow{2}{*}{ Weather } & \multirow{2}{*}{$\begin{array}{l}\text { Number of } \\
\text { occasions }\end{array}$} & \multicolumn{2}{|c|}{ Concentration of nuclei per litre at Delhi. } & \multirow{2}{*}{$\begin{array}{c}\text { Ratio of chloride } \\
\text { to ice-forming } \\
\text { nuclei }\end{array}$} \\
\hline & & Ice-forming & Chloride & \\
\hline 'CLEAR' & 101 & $41.2 \times 10^{-3}$ & 107.1 & $2.6 \times 10^{3}$ \\
\hline 'DUSTSTORM' & 23 & $43.9 \times 10^{-3}$ & 492.0 & 11. $2 \times 10^{3}$ \\
\hline
\end{tabular}

of soils can produce them. The present finding, which did not show increase in the ice nuclei count on dust storm days at Delhi, suggests that the soil dusts of northwest India, specially of the Rajasthan desert, which largely contribute for the dust storms in the Delhi region, has no special ice-nucleating ability.

(f) Concentration of ice-forming nuclei at Delhi and Calcutta.

The mean of the observations made in each month during the period December 1966 to February 1967 for Delhi and Calcutta is shown in Table 5.

Table 5 .

\begin{tabular}{lccc}
\hline \multirow{2}{*}{ Place } & \multicolumn{3}{c}{$\begin{array}{c}\text { Concentration (no/m } \\
\text { of ice-forming }\end{array}$ nuclei } \\
\cline { 2 - 4 } & $\begin{array}{c}\text { December } \\
1966\end{array}$ & $\begin{array}{c}\text { January } \\
1967\end{array}$ & $\begin{array}{c}\text { February } \\
1967\end{array}$ \\
\hline Delhi & 34.3 & 38.1 & 55.6 \\
Calcutta & 7.7 & 10.4 & 12.2 \\
\hline
\end{tabular}

The concentration of the ice-forming nuclei is higher in Delhi (well inland, about $900 \mathrm{~km}$ from the sea) than in Calcutta (nearer the coast, about $100 \mathrm{~km}$ from the sea), the mean values during the period for the two regions respectively being $39.5 / \mathrm{m}^{3}$ and $10.3 / \mathrm{m}^{3}$. The wind at Delhi during this period is from west to northwest (continental). Though Calcutta is nearer the coast, the wind flow in the region during the period is from inland, i.e. from north to northwest. There is, however, a difference in the character of the airmasses over the two regions (Roy 1946). It is modified polar continental to tropical continental at Calcutta. But, at Delhi, it is polar continental and, also sometimes, tropical continental/tropical maritime in the lower regions with modified polar continental above. Air from the Deccan plateau is drawn into north India under the influence of the passing western disturbances during this period. The relatively high value of the ice nuclei content observed during the period at
Delhi suggests, therefore, that wind-blown aerosols from the Deccan plateau, which are transported northward, possess ice-nucleating ability. The contention is somewhat supported by the fact that the concentration of the ice-forming nuclei during a similar period, i.e. from December 1967 to February 1968, studied at Poona- a region in the Deccan Plateau-is found to be equally high $\left(34.7 / \mathrm{m}^{3}\right)$ although comparison of the aerosol state of one place during one year with the aerosol state of another place during another year is not justified. Also, it is seen that whereas the difference in the content of the hygroscopic aerosol between the two regions (Delhi and Calcutta) is negligible (the mean values respectively are $0.8 / 1$ and $0.6 / 1$ ), it is not so as the non-hygroscopic aerosol is concerned. The mean concentration of the non-hygroscopic aerosols at Delhi during this period $(61.7 / 1)$ is 3 to 4 times that at Calcutta $(16.5 / 1)$ i. e. in nearly the same proportion as the ice nuclei content at Delhi is higher than the ice nuclei content at Calcutta. Such close association of the ice-nuclei content with that of the non-hygroscopic nuclei further suggests that the former could be mainly of land origin.

(g) Ice-forming, hygroscopic and non-hygroscopic nuclei at Poona.

The mean of the observations made in each month for the period December 1967 to June 1968 is shown plotted in Fig. 4. The fraction of the hygroscopic aerosol in the total is also shown in the figure. Note that the concentrations given for the hygroscopic and non-hygroscopic nuclei are for a wider size range as already mentioned in 2.

The observations point out a nearly parallel trend of variation in concentration between the ice-forming and the non-hygroscopic aerosols (correlation coefficient $\gamma=+0.758$ significant at 10 per cent level). Also, the fraction of the hygroscopic aerosols showed sharp increase from the month of May (from $39 \%$ in April to $70 \%$ in May) which period coincides with a change over in the prevailing flow from dry continental 


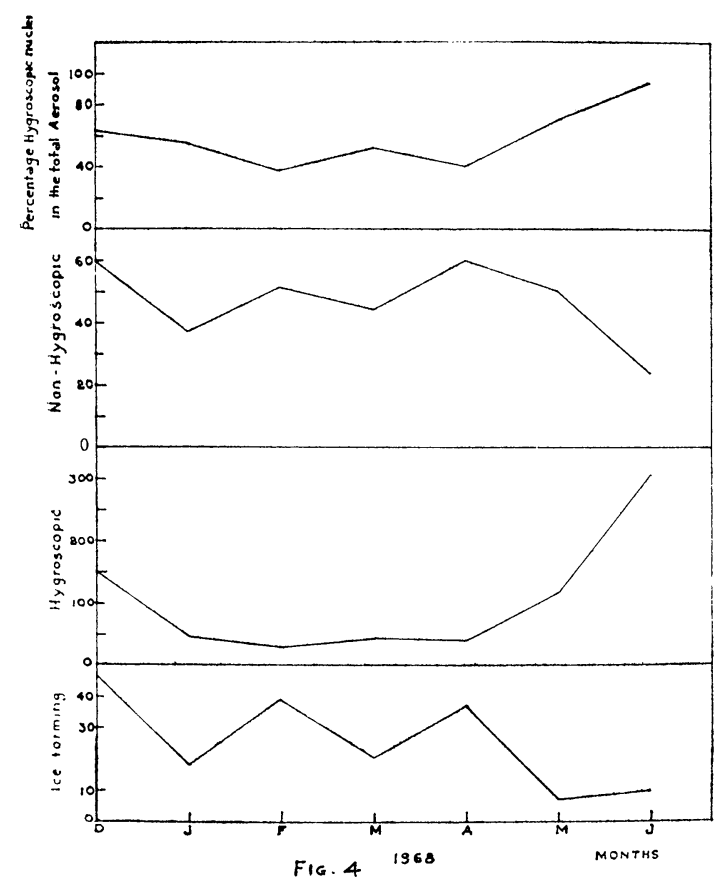

Fig. 4. Monthly mean concentration of iceforming $\left(\mathrm{no} / \mathrm{m}^{3}\right.$ at $\left.-15^{\circ} \mathrm{C}\right)$, hygroscopic, non-hygroscopic nuclei (no/1) and percentage of hygroscopic nuclei in the total aerosol at Poona.

to moist maritime. The concentration of the iceforming nuclei is higher from December to April (mean value: $31.9 / \mathrm{m}^{3}$ ) when the flow is from the east with longer land history than during MayJune (mean value: $7.8 / \mathrm{m}^{3}$ ) when the flow is from the west with reduced land history. The features suggest more of land-origin to the ice nuclei.

(h) Ice-forming and chloride nuclei concentration at Bombay, Lonavla and Poona.

Observations have been made at Bombay (coast), Lonavla $(55 \mathrm{~km}$ from the coast and situated near the crest facing the wind) and Poona $(110 \mathrm{~km}$ from the coast and situated leeward, in the plateau region), across the Western Ghats, on 6 days in the month of June 1968. The prevailing flow at the places during this period was from the west, i.e. from the sea. The time of sampling at Poona was about 3 hours later than that at Bombay which was the expected time the air would take from the coast to reach Poona. Sampling was done at Lonavla about $3 / 4$ to 1 hour earlier than at Poona. The results are illustrated in Fig. 5.

The concentration of the ice nuclei at Lonavla is higher than that at Bombay on 5 of the 6 days sampled, the mean values at the two places res-

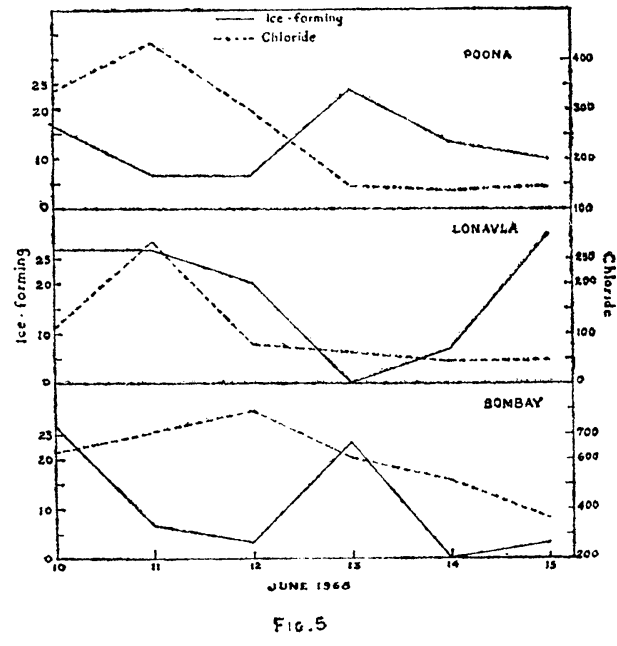

Fig. 5. Concentration ice-forming $\left(\mathrm{no} / \mathrm{m}^{3}\right.$ at $-15^{\circ} \mathrm{C}$ ) and chloride (no/1) nuclei at Bombay, Lonavla, and poona.

pectively being $26.7 / \mathrm{m}^{3}$ and $10.6 / \mathrm{m}^{3}$ indicating the possible influence of city (Bombay) air on the ice nuclei concentration downwind. The concentration of the ice nuclei at Poona was, on the mean, nearly the same $\left(12.8 / \mathrm{m}^{3}\right)$ as at Bombay. The variation in the concentration at Bombay is nearly parallel to that at Poona but the variation at Lonavla is somewhat anti-parallel to that noticed at Poona. The ice-forming and chloride nuclei showed inverse trends of variation at Bombay and Poona but no specific trend at Lonavla. The number of observations available is small to warrant any conclusion.

\section{Discussion}

The hygroscopic aerosols at Delhi during the monsoon season being largely of marine origin (Ramana Murty et al, 1962) the large chloride component of the hygroscopic aerosols observed during the period is mostly from the sea. The source of non-hygroscopic aerosols at all the places, by virtue of their property, is the land. The inverse association observed between the ice-forming and chloride nuclei, considered monthwise and seasonwise for Delhi, suggested that the source of the ice-forming nuclei is predominantly the land. The feature is corroborated by the observed behaviour of the iceforming nuclei with that of the hygroscopic nuclei which indicated a correlation coefficient of -0.650 , significant at 2 per cent level. The observed concentration of the ice-forming nuclei at Delhi during the winter period, which is four 
times that observed in the region during the monsoon season, further substantiated this view point. The continental air masses, as in the winter season, which are rich in aerosols of land origin are also found to be rich in iceforming aerosols. Parallel measurements made at Delhi and Calcutta and measurements made at Poona have enabled a similar inference to be drawn about the predominant source region of these nuclei. It is of interest to note that measurements made in England, with the very much improved technique for measurement of iceforming nuclei, pointed out that a larger proportion of the total number of the nuclei in the region were of continental origin (Stevenson 1968).

The observations made at Bombay have pointed out the ice-nuclei state of the maritime air (mean concentration: $10.6 / \mathrm{m}^{3}$ at $-15^{\circ} \mathrm{C}$ ) in the region. Equally low or very much lower values have been reported in the maritime airmasses, as for example, less than 100 per cubic metre at $-20^{\circ} \mathrm{C}$ in the air from the Pacific Ocean (Isono et al, 1959), 500 per cubic metre at $-24^{\circ} \mathrm{C}$ in Hawaii (Price and Pales, 1964) and less than 2 per litre at $-18^{\circ} \mathrm{C}$ at Eskdalemiur in England (Stevenson 1968). The question which, however, arises in this context is about the source region of these nuclei in the maritime air. Investigations have shown that significant quantities of continental material are carried out to sea by prevailing winds (Prospero, 1968). Large quantities of dust are found regularly transported across the Atlantic. A marked seasonal periodicity in the transport of dust was also observed, the average dust concentrations for the summer months being approximately an order of magnitude larger than those for winter months. If it is now considered that the dust over the seas carried from the continents in the manner as above retains part of its original ice-nucleating ability-about half of the mass of African dust samples collected are found to consist of Kaolinite and Illite (Delany et al) which are known for their most efficient ice-nucleating property-the source of origin of the ice-forming nuclei even in the maritime air-masses could also be conveniently traced back to the continents. The dominant source region of the ice-forming nuclei appears to be, therefore, the continents. These nuclei may be clay mineral particles (Kumai, 1961) which are flown from dry soils and also industrial smokes which are emanated from metal works in urban areas (Telford, 1960; Langer, 1967).

\section{Conclusion.}

Observations reported in the present study and also those reported in the literature have shown that the concentration of the ice-forming nuclei in the coastal regions is smaller than that in the inland regions. The maximum concentration (number per cubic metre at $-15^{\circ} \mathrm{C}$ ) noticed during the 6-day observational period at Bombay is 26.7 whereas measurements made at Delhi indicated that the maximum concentration there could reach as high a value as a hundred or more. The finding suggests that the mechanism of rain development in coastal regions, at least in the tropics, does not frequently involve icephase but may be associated predominantly with collision-coalescence process. The inference lends support to the often-reported pilots' statements that the rain at Bombay during the monsoon season is restricted to below the freezing level. The feature pointed out demands critical examination through systematic observations by radar, for its determination has an important bearing on the rain augmentation methods if any to be attempted in such areas. The presence in the air of higher concentrations of ice-forming nuclei in the inland region (Delhi) suggests that clouds in such region do develop rain by ice-crystal mechanism as well. Investigations by radar have confirmed this view point (Ramana Murty et al, 1960). The nuclei state of the air which is, therefore, a problem of considerable meteorological importance demands careful understanding with reference to various regions in the country characterized by different rainfall regimes.

The study suggested that dust of Deccan plateau could be a better natural ice nucleant than dust of the Rajasthan desert. As the inference drawn is based only certain possible meteorological considerations, the ice nucleating properties of these dust particles should be directly examined in conventional cold chambers.

\section{Acknowledgement}

The authors are thankful to Mr. K.V. Rao for the helpful suggestions received in course of preparation of the paper. They are thankful to Mr. B.N. Kanaday for the help received in the measurements made at Lonavla. Further, they express their deep sense of gratitude to the Division 
of Radio Physics, C.S.I.R.O., Sydney, Australia, for the ready help received in the processing of the millipore filters.

\section{References}

Battan, L.J., and J. J. Riley, 1960: Ice-crystal nuclei and maritime air. J. Meteor., 17, 675-676.

Bigg, E.K., and G.T. Miles, 1963: Stratospheric icenuclei measurements from balloons. Tellus, 15, 162-266.

, S.C. Mossop, R.T. Meade, and N.S.C. Thorndike, 1963: The measurement of ice nucleus concentrations by means of millipore filters. $J$. appl. Meteor., 2, 266-269.

Bourquard, A.D., 1963: Ice nucleus concentrations at the ground. J. atmos. Sci., 20, 386-391.

Brier, G.W., and D.B. Kline, 1959: Ocean water as a source of ice nuclei. Science, 130, 717-718.

Dalany, A.C., C.D. Audry, D.W. Parkin, J.J. Griffin, E.D. Goldberg, and B.E.F Reimann, 1967: Airborne dust collected at Barbados. Geochim, Cosmochim. Acta, 31, 885-909.

Georgii, H.W., and A.L. Metnieks, 1958: An investigation into the properties of atmospheric freezing nuclei and sea salt nuclei under maritime conditions at the west coast of Ireland. Geofis, Pura Appl. 41, 159-176.

Isono, K., M. Komabayasi, and A. Ono, 1959: The nature and the origin of ice nuclei in the atmosphere J. meteor. Soc. Japan, 37, 211-233.

Kapoor, R.K., and Bh. V. Ramana Murty, 1966: Sulphate aerosol at Delhi in relation to the associated chloride component. J. appl. Meteor., 5, 493-499.

Kumai, M., 1961: Snow crystals and the identification of the nuclei in the Northern United States of America. J. Meteor., 18, 139-150.
Langer, G., J. Rosinski, and C.P. Edwards, 1967: A continuous ice nucleus counter and its application to tracking in the troposphere. J. Appl. Meteor., 6, 114-125.

Lodge, J.P., Jr. 1954: Analysis of micron-sized particles. Anal. Chem., 26. 1829-1831.

Maruyama, H., and T. Kitagawa, 1967: Relation of meteor stream to natural ice nuclei and precipitation. J. meteor. Soc. Japan, 45, 126-136.

Price, S., and J.C. Pales, 1964: Ice nucleus counts and variations at $3.4 \mathrm{~km}$ and near sea level in Hawaii. Mon. Wea. Rev., 92, 207-221.

Prospero, J.M., 1968: Atmospheric dust studies on Barbados. Bull Amer. meteor. Soc., 49, 645-652.

Ramana Murty, Bh.V., A.K. Roy and R.K. Kapoor, 1967: Sources of origin and meteorological importance of hygroscopic and ice-forming nuclei. Tellus, 19, 136-142.

, K.R., Biswas, and B.K. Ghosh Dastidar, 1960: Incidence of 'warm' and 'cold' rain in and around Delhi, and their contributions to season's rainfall. Indian J. Meteor Geophys. 11, 331-346.

R. C., Srivastava, and R. K. Kapoor, 1962: Giant hygroscopic nuclei in surface air at Delhi. Indian J. Meteor. Geophys., 13, Spl. No. 9-16.

Rosinski, J., 1967: On the origin of ice nuclei. $J$. Atmos. Terr. Phys. 29, 1201-1218.

Roy A.K., 1946: Air masses in India. India Met. Dept. Tech. Notes No. 16.

Stevenson, C.M., 1968: Preliminary results from an investigation into the sources of freezing nuclei. Proc. Intern'l Conf. on Cloud Physics, Aug. 26-30, 1968, Toronto, Canada, 222-226.

Teleford, J. W., 1960: Freezing nuclei above the Tropopause. J. Meteor., 17, 86-88.

\title{
氷晶核とその重な発生地
}

\author{
R.K. カプール・R.S. 七クホン・A.S. ラマチャンドラムムルィ・Bh.V. ラマナムルティ \\ 印度気象局熱帯気象研究所, プーナ
}

インドの数ケ所の地点（デリー, カルカッタ, ボンベイ, ロナブラ, プーナ）で氷晶核と他の種類の核の濃度につ いて行なわれた観測データーの解析結果が述べられる.

米晶核はデリーとボンベイとプーナでは $\mathrm{Cl}$ 核と通常逆関係で变化した。デリーでは, 氷晶核と吸湿性核は負の相 関を示した. プーナでは氷晶核と非吸湿核は平行関係にあった. カルカッタと比べてデリーの氷晶核の比較的大きな 值は，その地方で観测された非吸湿性核の高い値と関わりがあるように見うけられた。観測の結果からすると，測定 地での氷晶㤥の主な起源は陸上であると思われる. 海洋性気団の中で観測された氷晶核について大陸性の塵埃が最も 可能性のあるものとして指摘された。 